\title{
E-Government Strategy and its impact on Economic Development of the Nation: A Case Study of the KSA
}

\author{
Abdulhameed Al-Khateeb ${ }^{1}$, Ahmad Faloudah ${ }^{2}$, Moayd Bahumayd ${ }^{3}$, Aasim Zafar ${ }^{4}$ \\ Faculty of Computing and Information Technology, Department of Information Systems, King Abdulaziz University, \\ Jeddah, Kingdom of Saudi Arabia 1,2,3,4
}

\begin{abstract}
Almost all governments in the world nowadays are implementing e-government for the purpose of costs reducing, services improving, time saving and increasing effectiveness and efficiency in all sectors of the government. That is why e-government became one of the primary target for Saudi government and all its agencies. This paper will discuss the main strategies and their impact on economic development of the Saudi nation and the efforts taken for implementation and the consciences been made to fulfill the strategies of the Saudi initiatives. It will also define the EGovernment and presents the most common advantages of e-government. However, e-government program normally expected to face many challenges and barriers, may be technological, cultural, organizational, or social issues. These have also been discussed in this paper.
\end{abstract}

Keywords: E-government, E-service, E-strategies, Economic Impacts.

\section{INTRODUCTION}

Information and Communication Technology (ICT) has As a result, most experts described the concept as follows: influenced our lives to some extent anyhow, with its - According to OECD (2004), E-government is the powerful characteristics that dramatically changed the way use of information and communication technology (ICT), people act, and interact with each other and their and particularly the internet, as tools to achieve better government. After the evolution of e-commerce in the government [17].

private sector, e-government looks to be the coming - The Ben Peacey (2002) defined e-government as the generation of the development. Developing strategies to use of ICT to improve the efficiency effectiveness run an e-government system is becoming as one of the top transparency and accountability of government. This aims for governments. E-government is becoming very definition also focuses on the area of impact on crucial action for changing the whole government agencies government [1].

with use of ICT. In the past, they used to focus on internal automation through introducing data processing machines to gain more efficiency in internal procedures and processes. E-government services and the use of electronic services could be an essential factors to promote and develop countries. On the other hand the online services are always available twenty-four hours a day, citizens have the chance to use and get access to information and services at their convenient time. Citizen satisfaction is the main target; at long run, satisfaction will lead to a great success of relationship between government, citizens and private sectors [15]. The rest of this paper describes factors for the adoption of e-government, its advantages, experience of e-government in developing nations and its impact on economy. We have taken Saudi Arabia as a case study and discussed various e-government initiatives in Saudi Arabia and its impact on Saudi economy.

\section{E-GOVERNMENT}

There are so many definitions that describe the egovernment concept, but each one looks at it from a deferent angle and perspective of the knowledge, therefore no such a definition has been accepted widely among experts.

E-government simply means is the use of technologies of communication and information, especially the use of the applications over the Internet, to make the access to government information and services available to citizens and insure the services quality is presented with complete democracy [14].

In this rapidly devolving world the challenges and opportunities are increasing notably, citizens and governments are enforced to cooperate and work efficiently and effectively to face the great challenges in the field of communication technologies. Therefore, initiatives have been taken by governments to use the electronic communication for developing its nations. Normally the government process services by passing through several departments, agencies, offices and sectors. Each government normally provides services mainly to the followings:

- Government to public is explored in the form of presenting services such as university admission, employment service and residency permit [6].

Government to businesses is delivering services to businesses such as commercial registration, work permits and restaurant license [6]. 
- Government to government is same as the processes of payment orders and an employee promotion service. They are not supposed to be for the end users, they are supposed to create an improved and better functions [6].

All these actions and interactions are preformed through applications and portals. E-Government applications are normally implemented in four-phases. First phase is to publish the information on a website and make it available for citizens how are looking for knowledge. The second phase is to make the site open and free for citizens so that they can interact and download the proper applications for receiving services. The third phase is making the electronic delivery of documents passible. The fourth phase is making the electronic delivery of services passible through more than one government departments.

\section{A. ADOPTION OF E-GOVERNMENT}

Actually we have so many definitions for the citizen adoption of e-government. Some researchers refer to it as the 'intention' or 'willingness' of a citizen to use egovernment information and services. Gefen et al (2002) defined e-government adoption as "the intention to 'engage in e-government", which encompasses the intentions to receive information, to provide information and to request e-government services [4].

Reddick (2005) classified the existing e-government into two streams of e-government adoption research: supplyside and demand-side. The first stream studies egovernment adoption from the supply-side perspective, which reflects the factors that are important or related to the supplier of public services .Therefore, this perspective explores factors that affect government organizations adoption and implementation of e-government services. Examples of these factors include IT infrastructure, financial resources, skilled personnel, and resistance to change. The second stream studies e-government adoption from the demand-side perspective, which focuses on the "customers" of public services [3]. Several researchers explored factors that influence citizens to adopt and use egovernment services. Examples of these factors include trust, culture, and perceived ease of use, perceived usefulness, and experience. However, while the academic literature on e-government adoption has focused upon the supply-side perspective [11].

\section{B. ADVANTAGES OF E-GOVERNMENT}

The advantages of e-government may be summarized as follows:

- Transparency: E-Government establishes the act of transparency between parties and deferent activities and transactions.

- Limiting corruption: Controlling resources and incomes conceder one of the top priority to governments like the action of corruption.

- Stablishing confidence: Hence interactions between parties with more confidence.

- Efficiency: Expedite transactions efficiently and faster.
Helps in developing all sectors: Rapid developing to deferent government agencies and external agencies.

Availability: Availability feature is present since the data is stored in digital format and can be accessed virtually.

- More Comprehensive: With the use of software applications deferent data mining can be preform as required.

- Learning free feature: Comparisons and differentiate the present and the past.

Revolve ICT industry: More experience to the local ICT industry to compete with the others.

\section{III.COMMON GOALS AND STRATEGIES}

Some of the developing countries invest their advanced ICT infrastructure in e-government due to their nation's needs and expectations towards providing a better, faster and efficient services same as the privet sectors [14]. Governments look forward to switch citizens into selfservice to save costs and time for both citizens and government. Some countries also look at e-government as a factor that influences economy directly activities like developing industry and attracting investments require a hard effort to be implemented with the use of egovernment. There has been a big change in the economy due to the effect that has been made by e-government and the way the information and internal administration set in the privet sector. Many countries recently building IT applications think they can get the advantages of the new technologies [14].

\section{E-GOVERNMENT STRATEGIES IN SAUDI ARABIA}

The Kingdom of Saudi Arabia (KSA) introduced more than one programs to their citizens and habitants. The beginning was when ministry of information and communication technology jointly with ministry of finance established e-government program, which is called Yesser in 2005. Yesser stimulate application the egovernment dealing and coordinate between government organizations [16].

This program aim to achieve the followings: Improving the productivity of public sector.

Introducing better and easy services for people, society and business sector.

- Increase the revenue of investments.

- $\quad$ Provision true information on demand in the time.

The developments of e-government programs in Saudi Arabia came after cooperation between different government sectors to putting strategy plans. The KSA government put two strategy plans, each plan is of five years duration. First plan started in 2006 and finished at 2010. This plan included Infrastructure projects, Electronic services projects and National applications projects. The Second plan started in 2012 and will finish in 2016.This plan consist of three main objectives, namely, Increasing efficiency of services, Development of collaboration and Enhancement the experience of citizens to dealing with e government programs. Every year 
performance evaluation are done to measure the results and found mistakes and then try to solve it [16].

Since KSA started implementing e-government strategies in 2006, people started noticing the change and development in government services. This development included the reduction of time of services delivery and ease obtaining them. Globally KSA progressed in United Nations ranking of e-government readiness. The figure 1 represent improved rating of KSA from 105 at 2003 to 36 at 2014.

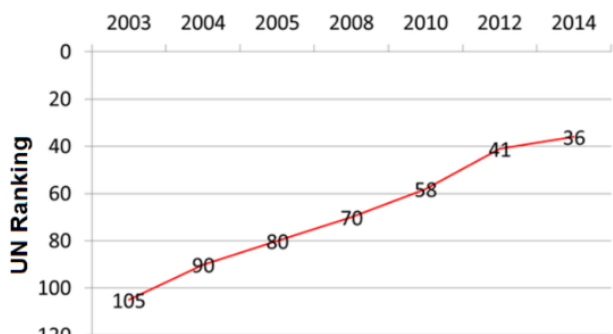

FIGURE 1: KSA IN UN RANKING OF EGOVERNMENT READINESS

(REFERENCE [7]:

HTTP://WWW.YESSER.GOV.SA/AR/TRANSFORMATION_INDIC ATORS/INTERNATIONAL_INDICATORS/PAGES/2014UN_INDICATOR.ASPX).

\section{IV.E-GOVERNMENT EXPERIENCES IN DEVELOPING COUNTRIES}

It is noted from the previous experiences that the eGovernment services success is always measured by the indications of the satisfaction of users. For example in Jordan, most of the Internet users who tried the eGovernment applications have affected the demand on. more services [13]. The same thing goes in the USA egovernment, once the level of services improve in value, the user number, demands and interactions with egovernment increase. Since the emphasis is aiming at the citizens need and relationship with e-government, then it would definitely be reflected on whole society and economy of the country. User satisfactions and experience with e-government is good indication of increasing of demand on services [13].

\section{E-GOVERNMENT INITIATIVES IN SAUDI ARABIA}

The e-Government initiative in Saudi Arabia is considered as one of the ICT major project, and it was the result of the invested efforts from the government side in order to have a great outcome to the country through the following aims [14]:

- Enhance the government services and quality that is presented to citizen, private sectors and Government users. - Insure efficiency and effectiveness factors are implemented to minimize cost and maximize production.

- $\quad$ Encourage the distributing and using of information and knowledge.

The strategies related to e-government in Saudi Arabia may be summarized as follows:
E-government is a new way to redesign the management \& service processes in government organizations.

E-government requires to modify old regulations to be compatible with new services and processes.

Improve and enhance processes is a main step before convert to e-government because complexity processes will not be useful.

E-government depends on using new technology (hardware and software's).

- E-government converts the relation and contact between citizen and government organizations to be in easy and effective way.

- $\quad$ E-government firstly aims to satisfy citizen and we can measure the success by measure citizen's satisfaction.

- E-government facilities query and contact with government organizations 24/7.

- The evaluation of e-government lead to enhance contact between nation, service enterprises and government organizations that cause develop on economic.

- E-government plays the main role in overcome the financial corruption.

The Yesser e-government program appeared on the surface to play its main role as facilitator and focal point between government and other agencies. The vision for Saudi Arabia's e-government initiative had set a statement which aimed to: "By the end of 2010, everyone in the Kingdom will be able to enjoy - from anywhere and at any time - world class government services offered in a seamless, user friendly and secure way by utilizing a variety of electronic means" [16].

\section{NATIONAL CONTACT CENTER (AMER)}

The idea of National Contact Center is to help, support and respond to queries of the Saudi community on eGovernment such as inquiries or procedures providing by government agencies to citizens and residents.

The examples of contact center's services are:

Telephone (mobile, IVR whether international or local, SMS) by 199099.

- Internet (Browsing, e-mail, live chat) by www.199099.gov.sa.

- $\quad$ FAX and post.

- Social communication networks.

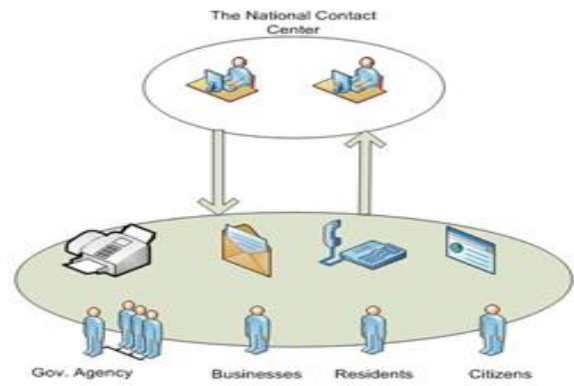

FigURE 2. NATIONAL CONTACT CENTER

(REFERENCE:

HTTP://WWW.YESSER.GOV.SA/EN/BUILDINGBLOCKS/PAGES /NATIONAL_E-GOVERNMENT_CONTACT_CENTER.ASPX) 


\section{B. DIGITAL CERTIFICATION}

The idea of National Center for Digital Certification is to provide integrated system for management of the (Public Key Infrastructure-PKI). The security keys are used for achieving information system confidentiality, authentication of user's identities. On the other hand, to ensuring data integrity against tampering and change, and using digital signatures, these keys are used in egovernment and e-commerce.

\section{SAUDI PORTAL}

The idea of Saudi Portal is that the users can access egovernment services online from anywhere and anytime such as citizens, residents and businesses through internet. The real examples in KSA are General Directorate of Passport (Absher) and the ministry of Commerce and industry.

\section{A. GENERAL DIRECTORATE OF PASSPORT (GDP) "ABSHER"}

An electronic service application called Absher was launched recently through electronic gate of ministry of interior for GDP. Absher is e-service that will facilitate the procedures on the citizen and visitors to end all his papers through the internet, without forcing him to come to the headquarters of the passport, collaboration with the National Information Center.

The Absher programs includes:

- The issuance of travel permits and canceled.

- The issuance of residence and renewal.

- The issuance of visas and canceled.

- Access to personal data and data of family.

- Query of perform the Hajj, health insurance, new worker and visitors.

- And there are many of services for some sectors of government.

The statistics issued by Directorate General of Passports in Riyadh related to e-services provided to citizens and residents till the last year, (i.e., 2014) is given below [12].

- $\quad$ The issuance of travel permits 324,745 .

- The issuance of residence 301,603 and renewal $2,759,110$.

- $\quad$ The issuance of visas and return 4,215451.

- $\quad$ The issuance of visas and final exit 214,080.

- The issuance of Saudi Passport 20,224.

- $\quad$ Transport services 165,862 .

- $\quad$ Amendment careers 128,861

- $\quad$ Authorization electronically 4252 .

This statistics revealed the number of registered users in "Absher" has gone up to three million and a half subscribers, and 30 thousand commercial facility employs and more than four million workers [12]. These statistical data reflect the beneficiaries and the diversity of services offered and increase in the acceptance rate. Really, Absher services are impacting the economic development of KSA in terms of providing all services through internet to facilitate and improve business process and facilitate the procedures on the citizen and visitors [12].

\section{THE MINISTRY OF COMMERCE AND INDUSTRY}

The ministry of commerce and industry (MCI) is looking forward to serve the people, business sector, government agencies by providing different facilities through eservice. In this way it will be much easier to solve their orders and requests from any city without the need to visit the ministry building.

\section{TABLE 1. SERVICES PROVIDED BY MCI TO VARIOUS SECTORS}

\begin{tabular}{|c|c|}
\hline $\begin{array}{l}\text { The commercial registration } \\
\text { and contract of companies: } \\
\text { Issuing commercial register } \\
\text { customs } \\
\text { Query for commercial name }\end{array}$ & $\begin{array}{l}\text { Customs Exemption: } \\
\text { Inquire about the request to } \\
\text { exempt } \\
\text { Customs exemption system }\end{array}$ \\
\hline $\begin{array}{l}\text { Consumer's affairs: } \\
\text { Inquire about the food price } \\
\text { Report for any commercial } \\
\text { cheat }\end{array}$ & $\begin{array}{l}\text { Factory guide: } \\
\text { Factory information } \\
\text { Update the factory data }\end{array}$ \\
\hline $\begin{array}{l}\text { Licenses: } \\
\text { Emission Industrial license } \\
\text { Request the support of labor }\end{array}$ & $\begin{array}{l}\text { Trademarks: } \\
\text { Trademarks service } \\
\text { Find tag number }\end{array}$ \\
\hline $\begin{array}{l}\text { Other services } \\
\text { Follow-up statement } \\
\text { Search in electronic } \\
\text { Exhibition Guide }\end{array}$ & \\
\hline
\end{tabular}

The ministry conducted a survey and announced the results of questionnaire for the measurement of consumer satisfaction with car agencies [9]. The result of the questionnaire shows non-satisfaction of the participants. $61 \%$ of consumers are never satisfied with the level of services provided, $11 \%$ of those who expressed their satisfaction, while $28 \%$ said they were fairly satisfied. The ministry communicates these results to the manufacturer, asking companies to follow-up on the performance of its agents to ensure the improvement and upgrading of services provided to consumers.

\section{KAFALAH PROGRAM}

Kafalah is a Saudi program that supports small and medium enterprises by introducing loans for them to improve gross domestic product and provide job opportunities for increasing employment. This program contributes in development of Saudi society in the whole regions of KSA. The beneficiaries from loans have invested in different fields, construction, property, and trade or even in stocks which has reflected a positive impact on Saudi economy [2].

TABLE 2. DETAILS OF KAFALAH PROGRAM FROM 2006 TO 2014

\begin{tabular}{|c|c|c|c|}
\hline Year & $\begin{array}{c}\text { No of } \\
\text { Enterprises }\end{array}$ & $\begin{array}{c}\text { Loan } \\
\text { Sanctioned } \\
\text { ( SR) }\end{array}$ & $\begin{array}{c}\text { Funding From } \\
\text { Bank (SR) }\end{array}$ \\
\hline $\mathbf{2 0 1 4}$ & 652 & 311,567 & 571,832 \\
Million & Million \\
\hline $\mathbf{2 0 0 6}$ to & 7932 & $3,901,388$ & $7,756,222$ \\
$\mathbf{2 0 1 3}$ & & Million & Million \\
\hline
\end{tabular}

(Reference [5]: http://unpan3.un.org/egovkb/en-

us/Data/Country-Information/id/149-Saudi-Arabia) 


\section{VI.DIRECT ECONOMIC IMPACTS OF E- GOVERNMENT}

In the following sections, we discuss the impact of egovernment on economy of a nation.

\section{A. HELPS IN REDUCING COST OF THE SERVICES PRESENTED}

Nowadays so many e-government applications have been launched to help governments to reduce cost, but in fact, cost reduction has not taken place as it expected. Up to this point the cut back in the number of employs who deliver services in the traditional way is expected, also reduction in costs is expected [14]. This has also limited the use of the internet in most of the developing countries.

\section{B. HELPS IN CONTROLLING GOVERNMENT BUDGET}

Many countries are using e-government systems for managing financial issues. Some of these systems concentrate on expenditure control, not exploiting the full potential of the system to combat corruption and improve service deliver [14]. Another way of controlling expenditure is to work with paper less offices in government agencies. However, more potent savings through downsizing of governments has not yet happened because of the strong resistance from well-organized unions of Government employees [14].

\section{HELPS IN INCREASE OF INCOME}

The shortage of controlling and enforcing the taxes payment in many countries caused a cash-strapped to government. Corruption is always present in a poor control of the process of collecting tax money that result a big loss to government and citizens. Governments nowadays use online applications to minimize corruption and maximize trust among citizens. For example in Mexico the e-SAT application collected $80 \%$ of tax revenues and saved the costs of the process. Also in Chile government has saved their lot of money by using the Tax Online System [14].

\section{IMPACT OF E-GOVERNMENT ON ECONOMY OF SAUDI ARABIA}

We have cited some of the major e-government applications along with their advantages and impact on Saudi economy and this has been summarized in Table 3.
TABLE 3. DIRECT IMPACT OF MAJOR E-GOVERNMENT APPLICATIONS ON SAUDI ECONOMY

\begin{tabular}{|c|c|c|c|}
\hline Application & Area & Direct impact & Advantage \\
\hline Tadawul & $\begin{array}{l}\text { Stock exchange } \\
\text { market }\end{array}$ & $\begin{array}{l}\text { - Controlling and authorizing Stock } \\
\text { exchange market by the Capital } \\
\text { Market Authority. } \\
\text { - Allow the forign and local Stock } \\
\text { exchange and trading of Saudi } \\
\text { stocks. } \\
\text { - Legalized online stock market } \\
\text { transactions. } \\
\text { - Facilitated KSA membership in the } \\
\text { World Trade Organization. } \\
\text { - Forming a great environment and } \\
\text { condition for foreign investment and } \\
\text { world trade. } \\
\text { - Free trading process and } \\
\text { country's economy to react with } \\
\text { world markets and economy. }\end{array}$ & $\begin{array}{l}\text { - Increase of Managers } \\
\text { tools for controlling and } \\
\text { monitoring task } \\
\text { completion. } \\
\text { - Increase of efficiency of } \\
\text { services presented, by the } \\
\text { automating processes and } \\
\text { procedures. } \\
\text { - Use of databases, insure } \\
\text { the integration of trusted } \\
\text { information. } \\
\text { - Improve the Efficiency } \\
\text { and speed of workflow } \\
\text { and data exchange } \\
\text { between agencies. }\end{array}$ \\
\hline Yasser & $\begin{array}{l}\text { Presents } \\
\text { services to } \\
\text { government } \\
\text { agencies and } \\
\text { privet sectors }\end{array}$ & $\begin{array}{l}\text { Add a tangible value on efficiency } \\
\text { and production process in the public } \\
\text { sector by expediting actions. } \\
\text { - Presents a simple and easy } \\
\text { services for business and individuals } \\
\text { levels. } \\
\text { - Increase local and forging } \\
\text { investments returns } \\
\text { - Presents required information for } \\
\text { users of Stock exchange market. } \\
\text { - Provide government agencies with } \\
\text { information and knowledge in no } \\
\text { time by the use of advanced } \\
\text { technology. }\end{array}$ & $\begin{array}{l}\text { - Fast completion of } \\
\text { transactions. } \\
\text { Reduce expenses of } \\
\text { traveling for citizens } \\
\text { who use to come to the } \\
\text { place of the government } \\
\text { agent. } \\
\text { - Insure the delivery of } \\
\text { services to most of the } \\
\text { population. }\end{array}$ \\
\hline $\begin{array}{l}\text { National } \\
\text { Contact } \\
\text { Center }\end{array}$ & & $\begin{array}{l}\text { Support and respond to queries of } \\
\text { the Saudi community. } \\
\text { - Inquiries or procedures providing by } \\
\text { government agencies to citizens and } \\
\text { residents. }\end{array}$ & \\
\hline Absher & $\begin{array}{l}\text { Electronic gate } \\
\text { of ministry of } \\
\text { interior }\end{array}$ & $\begin{array}{l}\text { - Facilitate the procedures on the } \\
\text { citizen and visitors to end all his } \\
\text { papers related to government } \\
\text { through the internet. }\end{array}$ & $\begin{array}{l}\text { - Reduce the time to } \\
\text { interact with government. } \\
\text { - Reduction of face to face } \\
\text { meeting between } \\
\text { government and } \\
\text { individuals. }\end{array}$ \\
\hline
\end{tabular}

\section{CONCLUSION}

Nowadays globalization has changed many countries considerations regarding technologies and made them look closely towards the increasing use of technologies. The increasing demand for technologies and e-government have been noticed at almost everywhere in the government and private sections, in order to have services presented to citizen via electronic means which known (electronic government).

The economy of KSA is rapidly growing due to the influences of technologies. Therefore, the government has created comprehensive overall development plans that feature a national e-government strategy. The Saudi economy, which relies very much on the production and export of oil for income, now is trying to make way for establishing a knowledge-based economy [8]. The widespread understanding will make it easy for Saudi Arabia government to join and share information with the rest of the world and society. The knowledge is the key factor for a good economy, which can facilitate advantages and benefits for a country (Webster, 2002). Considering this Saudi government initiated its plan of e-government project in 2005 with a primary aim to improve the internal effectiveness and efficiency of its agencies. The plan of the Government of Saudi Arabia is to swap the economy strategy from an oil production-based structure to a knowledge-based structure. Introduction of e-government is becoming a crucial side of these strategies which will facilitate a lot of services among citizens, government agencies and privet sectors. Therefore, a great and successful transaction in strategies like this will move the country towards a knowledge-based economy very fast. 


\section{REFERENCES}

[1] Ben Peacey. (2002). Socio-Economic Impacts of ICT: Egovernment@ the Local Level - A Discussion Paper. Sociology and Anthropology. Canterbury: University of Canterbury. Retrieved from. http://www.ssrc.canterbury.ac.nz/research/Technologies /E\%20Government\%20paper\%200xley-2.pdf

[2] Elizabeth R. Pfiester | SUSRIS. (2010, 12 4). Boosting Small and Medium Enterprises in Saudi Arabia. Retrieved from SUSRIS: SUSRIS.com

[3] G Reddick, C. (2005). Citizen interaction with e-government: From the streets to servers? Government Information Quarterly.

[4] Gefen, M Warkentin, P Pavlo, \& G Rose. (2002). E-government adoption. AMCIS.

[5] http://unpan3.un.org/egovkb/en-us/Data/CountryInformation/id/149-Saudi-Arabia. (2014). Retrieved from United Nations Public Administration Country Studies.

[6] Abdullah Mohammad Al Shehry, 2008, transformation towards Egovernment in the Kingdome of Saudi Arabia technical and organisational perspectives, the school of computing, CCSR,De Montfort University.

[7] https://www.yesser.gov.sa/ar/transformation_Indicators/internationa 1_indicators/Pages/2014-UN_indicator.aspx. (2014). Retrieved from Yesser.

[8] Ibrahim Abu Nadi. (2012). Influence of Culture on e-Government Acceptance in Saudi Arabia. Australia: School of Information and Communication Technology Science, Environment, Engineering and Technology Group Griffith University. Retrieved from http://arxiv.org/ftp/arxiv/papers/1307/1307.7141.pdf

[9] MCI. (2013, 6 23). The Ministry of Commerce and Industry in Saudi Arabia. Retrieved 3 15, 2015, from MCI: http://mci.gov.sa/MediaCenter/News/Pages/N00022.aspx

[10] Mohammad Kamel Alomari, Kuldeep Sandhu, Peter Woods. (2009). E-government Adoption in the Hashemite Kingdom of Jordan: Factors from Social Perspectives. Institute of Electrical and Electronics Engineers, Inc. Australia: Institute of Electrical and Electronics Engineers, Inc. Retrieved from http://www98.griffith.edu.au/dspace/bitstream/handle/10072/30854/ 6302? sequence $=1$

[11] Omar Al Hujran. (2013). Factors Influencing Citizen Adoption of E-Government in Developing Countries: The Case of Jordan. International Journal of Technology and Human Interaction (IJTHI), 9(2), 19.

[12] Sabq. (2014, 8 11). Sabq. Retrieved 3 15, 2015, from Sabq: http://sabq.org/origde

[13] Samer Mofleh, Mohammed Wanous. (2008). Understanding Factors Influencing Citizens' Adoption of e-Government Services in the Developing World: Jordan as a Case Study. United Kingdom: Bristol University, Engineering Management Group. Retrieved from http://www.dcc.ufla.br/infocomp/artigos/v7.2/art01.pdf

[14] Subhash Bhatnagar. (2003). The Economic and Social Impact of Egovernment. Indian Institute of Management, Ahmedabad. Indian: E-government, the citizen and the state: Debating governance in the information age (World Public Sector Report for 2003: EGovernment at the Crossroads). Retrieved from http://www.iimahd.ernet.in/ subhash/pdfs/UNDESAeGovReport.pdf

[15] Suha AlAwadhi, Anne Morris. (2009). Factors Influencing the Adoption of E-government Services. JOURNAL OF SOFTWARE, 4(6), $584 . \quad$ Retrieved from http://www.academypublisher.com/jsw/vol04/no06/jsw0406584590.pdf

[16] Yesser Program. (2015, 3 1). Yesser. Retrieved from Yesser: http://www.yesser.gov.sa/ar/Pages/default.aspx

[17] OECD, 2004 the E-government imperative .cedex 16 Paris, France. 